\title{
Inhibitory Effects of Red Ginseng on Passive Cutaneous Anaphylaxis and Scratching Behavior Reactions in Mice
}

\author{
Hien-Trung Trinh*, Eun-Ah Bae*, Myung Joo Han**, Yong-Wook Shin* and Dong-Hyun Kim*,\# \\ *College of Pharmacy and **Department of Food and Nutrition, \\ and Kyung Hee University, 1, Hoegi, Dongdaemun-ku, Seoul 130-701, Korea
}

(Received July 2, 2007; Accepted August 31, 2007)

\begin{abstract}
Abtract : To evaluate the antiatopic effect of Korea Red Ginseng (RG, steamed root of Panax ginseng C.A. Meyer, Family Araliaceae), its inhibitory effect on passive cutaneous anaphylaxis reaction and itching in mice was measured. RG and its ingredient saponin fraction (SF) potently inhibited passive cutaneous anaphylaxis (PCA) reaction and scratching behaviors. RG at a dose of $100 \mathrm{mg} / \mathrm{kg}$ and SF at a dose of $50 \mathrm{mg} / \mathrm{kg}$ significantly inhibited the scratching frequency by $32 \%$ and $38 \%$, respectively. RG and SF also inhibited the degranulation and protein expression of tumor necrosis factor (TNF)$\alpha$ and interleukin (IL)-4 of RBL-2H3 cells induced by IgE-antign complex. However, polysaccharide fraction of RG did not inhibit it. Based on these findings, RG can improve allergic skin disorders atopic dermatitis and contact dermatitis by the regulation of TNF- $\alpha$, and IL-4 produced by mast cells and basophils and their membrane stabilization.
\end{abstract}

Key words : Red ginseng, scratching behaviors, passive cutaneous anaphylaxis, atopic dermatitis, allergic activity.

\section{INTRODUCTION}

Red ginseng (RG, the steamed root of Panax ginseng C.A. Meyer, family Araliaceae) is frequently used as a traditional medicine taken orally in Korea, China, Japan and Asian countries. The major components of ginseng are ginsenosides and polysaccharides. ${ }^{1,2)}$ Many kinds of saponins, such as ginsenosides $\mathrm{Rb}_{1}, \mathrm{Rb}_{2}, \mathrm{Rc}$ and $\mathrm{Rf}$, have been isolated. However, RG contains genuine saponins, ginsenosides $\mathrm{Rg}_{3}$ and $\mathrm{Rh}_{2}{ }^{3,4}$. Ginsenosides $\mathrm{Rg}_{3}$ and $\mathrm{Rh}_{2}$ were produced from protopanaxadiol ginsenosides by steaming to prepare $\mathrm{RG}^{5)}$. These ginsenosides have been reported to show various biological activities including anti-inflammatory activity, antiallergic, endothelium-independent aorta relaxation and anti-tumor effects. ${ }^{6-9)}$ Particularly, Sugiyama et al. reported that ginsenoside $\mathrm{Rg}_{3}$ suppressed histamine release from mast cells caused due to stimulation with compound 48/80 (condensation product of N-methyl-p-methoxyphenethylamine with formaldehyde) in vitro ${ }^{10)}$

We also reported the antiallergic and anti-inflammatory effect of $\mathrm{RG}$ and ginsenoside $\mathrm{Rh}_{1}{ }^{11,12)}$, antiallergic and

\footnotetext{
\# To whom correspondence should be addressed.

(Tel) +82-2-961-0374; (Fax) +82-2-957-5030

(E-mail)dhkim@khu.ac.kr
}

passive cutaneous anaphylaxis reaction (PCA)-inhibitory effects of compound $\mathrm{K}^{13)}$ and antiallergic effect of ginsenoside $\mathrm{Rh}_{2}{ }^{6}$. However, antiatopic effects such as PCA reaction scratching behavior reactions, and its mechanism of RG and its ingredients saponins fraction (SF) and polysaccharide fraction (PF) have not been thoroughly studied.

Therefore, the present study is to investigate the inhibitory effect of RG, SF and PF on passive cutaneous anaphylaxis reaction and itching in mice.

\section{MATERIALS AND METHODS}

\section{Materials}

p-Nitrophenyl-N-acetyl- $\beta$-D-glucosaminide, Freund's complete adjuvant, anti-dinitrophenol (DNP)-IgE, DNP-human serum albumin (HSA), Evans blue, trichloroacetic acid, betamethasone, and azelastine were purchased from Sigma Chemical Co. (U.S.A). RG water extract was donated from KT\&G (Korea). SF and PF were isolated according to the previous reported methods ${ }^{15,16)}$.

\section{Animals}

The male ICR mice (20-25 g) were supplied from the Orient Co., Ltd, a branch of Charles River Laboratories (Seoul, Korea). All animals were housed in wire cages, 
maintained at $20-22^{\circ} \mathrm{C}$ and $50 \pm 10 \%$ humidity, fed standard laboratory chow (the Orient Co., Ltd), and allowed water ad libitum. All procedures relating to the animals and their care conformed to the international guidelines: 'Principles of Laboratory Animals Care' (NIH publication no. 85-23, revised 1985) and the Animal Care and Use Guidelines of Kyung Hee University, Korea.

\section{Passive Cutaneous Anaphylaxis (PCA) Reaction}

An IgE-dependent cutaneous reaction was measured according to the previous method of Choo et al. ${ }^{13)}$ The male ICR mice (25-30 g) were injected intradermally with $10 \mu \mathrm{g}$ of anti-DNP IgE into each of two dorsal skin sites that had been shaved $48 \mathrm{~h}$ earlier. The sites were outlined with a water-insoluble red marker. Forty-eight hours later each mouse received an injection of $200 \mu \mathrm{l}$ of $3 \%$ Evans blue PBS containing $200 \mu \mathrm{g}$ of DNP-HSA via the tail vein. The test agents were administered $1 \mathrm{~h}$ prior to DNPHSA injection. Thirty min after DNP-HSA injection, the mice were sacrificed and their dorsal skins were removed for measurement of the pigment area. After extraction with $1 \mathrm{ml}$ of $1.0 \mathrm{~N} \mathrm{KOH}$ and $4 \mathrm{ml}$ of a mixture of acetone and $0.6 \mathrm{~N}$ phosphoric acid (13:5), the amount of dye was determined colorimetrically (the absorbance at $620 \mathrm{~nm}$ ).

\section{Assay of scratching behavior frequency}

The scratching behavioral experiment in male mice was performed according to the method of Sugimoto et al. ${ }^{16)}$ Briefly, the mice were placed in acrylic cages $(22 \times 22 \times 24$ $\mathrm{cm}$ ) and allowed to acclimatize for about $10 \mathrm{~min}$. The rostral part of the skin on the back of the mice was clipped, and $300 \mu \mathrm{g} / 50 \mu \mathrm{l}$ of histamine in ICR mice then intradermally injected into each mouse. Immediately after the intradermal injection, the mice (one animal/cage) were placed back in the same cage, and the scratching behavior was recorded using an 8-mm video camera (SV-K80, Samsung, Seoul, Korea). The scratching frequency of the injected site with the hind paws was counted for $60 \mathrm{~min}$. The test agents were orally administered $1 \mathrm{~h}$ before the scratching agent.

\section{Assay of inhibitory activity against $\beta$-hexosamini- dase release of $\mathrm{RBL}-2 \mathrm{H3}$ cells}

The inhibitory activity of test agents against the release of $\beta$-hexosaminidase from RBL-2H3 cells was evaluated according to Choo et al. ${ }^{13)}$. RBL-2H3 cells were grown in Dulbecco's modified Eagle Medium supplemented with $10 \%$ fetal bovine serum and L-glutamine. Before the experiment, cells were dispensed into 24 -well plates at a concentration of $5 \times 10^{5}$ cells per well, and using a medium containing $0.5 \mu \mathrm{g} / \mathrm{ml}$ of mouse monoclonal $\mathrm{IgE}$, the cells were sensitized by incubation overnight at $37^{\circ} \mathrm{C}$ in $5 \% \mathrm{CO}_{2}$. They were then washed with $500 \mathrm{ml}$ of Siraganian buffer (pH 7.2, $119 \mathrm{mM} \mathrm{NaCl}, 5 \mathrm{mM} \mathrm{KCl}, 0.4$ $\mathrm{mM} \mathrm{MgCl}_{2}, 25 \mathrm{mM}$ PIPES, $40 \mathrm{mM} \mathrm{NaOH}$ ) and incubated in $160 \mu \mathrm{l}$ of Siraganian buffer containing $5.6 \mathrm{mM}$ glucose, $1 \mathrm{mM} \mathrm{CaCl}$ and $0.1 \% \mathrm{BSA}$ for additional 10 $\min$ at $37^{\circ} \mathrm{C}$. The cells were exposed to $40 \mu l$ of test agents for $20 \mathrm{~min}$, treated with $20 \mu \mathrm{l}$ of antigen (DNP$\mathrm{HSA}, 1 \mu \mathrm{g} / \mathrm{ml}$ ) for $10 \mathrm{~min}$ at $37^{\circ} \mathrm{C}$ to activate cells and to evoke allergic reactions. The reaction was stopped by cooling in an ice bath for $10 \mathrm{~min}$. The reaction mixture was centrifuged at $2000 \mathrm{rpm}$ for $10 \mathrm{~min}$ and $25 \mu \mathrm{l}$ aliquots of the supernatant were transferred to 96 well plates and incubated with $25 \mu$ of substrate ( $1 \mathrm{mM}$ p-nitrophenyl-Nacetyl- $\beta$-D-glucosaminide) for $1 \mathrm{~h}$ at $37^{\circ} \mathrm{C}$. The reaction was stopped by adding $200 \mu \mathrm{l}$ of $0.1 \mathrm{M} \mathrm{Na} \mathrm{NO}_{3} /$ $\mathrm{NaHCO}_{3}$. Absorbance was measured by using an ELISA reader at $405 \mathrm{~nm}$.

\section{Reverse transcription - polymerase chain reaction (RT-PCR)}

For isolation of mRNA from RBL-2H cells, the cultured cells were immediately placed in liquid nitrogen and pulverized in mortar. mRNA was extract from the pulverized tissue by using TRI reagent (Cincinnati, Ohio, USA) according to the manufacturer's instructions. The respective primer sets were prepared according to the method of Shin et $a l .{ }^{17)}$. The RT-PCR was performed with AccPower ${ }^{\circledR}$ RT/ PCR Premix (Bioneer, Seoul, Korea). Optimization of cycle number was performed to ensure that production accumulation was in the linear range. Amplified products were separated by electrophoresis on $1.5 \%$ agarose gel containing ethidium bromide. The gels were photographed under UV light. The GAPDH gene was used as an internal control. The signal intensity of each RT-PCR product was estimated by Shimazu 9301-PC scanner (Tokyo, Japan).

\section{Statistics}

All the data were expressed as the mean \pm standard deviation, and statistical significance was analyzed by one way ANOVA followed by Student-Newman-Keuls test.

\section{RESULTS}

\section{Inhibition of RG on PCA Reaction}

PCA reaction in mice was induced by the intradermal 
Table 1. Inhibitory effects of red ginseng and its ingredients on passive cutaneous anaphylaxis reaction in mice.

\begin{tabular}{ccc}
\hline \hline Agent & Dose $(\mathrm{mg} / \mathrm{kg})$ & Inhibition $^{\text {a) }}(\%)$ \\
\hline \multirow{2}{*}{ RG } & 100 & $32.0 \pm 6.6^{\mathrm{c}}$ \\
& 200 & $40.9 \pm 7.4^{\mathrm{c}}$ \\
SF & 25 & $31.5 \pm 4.5^{\mathrm{c}}$ \\
& 50 & $41.3 \pm 1.9^{\mathrm{c}}$ \\
PF & 25 & $14.2 \pm 2.4^{\mathrm{c}}$ \\
& 50 & $12.7 \pm 1.3^{\mathrm{c}}$ \\
Azelastine & 10 & $72.1 \pm 5.3^{\mathrm{d}}$
\end{tabular}

${ }^{a}$ The amounts of extravasated Evan blue from the dorsal skin (1 $\times 1 \mathrm{~cm})$ of the control stimulated with the IgE-antigen complex and vehicle-treated groups were $24 \pm 4$ and $9 \pm 2 \mu \mathrm{g}$, respectively. Each experiment consisted of six observations. All inhibitory values indicate mean \pm S.D.

$\mathrm{b}, \mathrm{c}, \mathrm{d}$ Those with the same letter are not significantly different in each column $(P<0.05)$.

Table 2. Inhibitory effects of red ginseng and its ingredients on the scratching behaviors induced by histamine in mice

\begin{tabular}{ccc}
\hline \hline Agent & Dose $(\mathrm{mg} / \mathrm{kg})$ & Inhibition $^{\mathrm{a})}(\%)$ \\
\hline \multirow{2}{*}{ RG } & 100 & $32 \pm 4.5^{\mathrm{d}, \mathrm{e}}$ \\
& 200 & $53 \pm 5.6^{\mathrm{f}}$ \\
SF & 25 & $30 \pm 5.2^{\mathrm{d}, \mathrm{e}}$ \\
& 50 & $38 \pm 5.9^{\mathrm{e}}$ \\
PF & 25 & $-{ }^{\mathrm{b})}$ \\
& 50 & $5 \pm 0.4^{\mathrm{c}}$ \\
Azelastine & 10 & $63 \pm 12.7^{\mathrm{f}}$ \\
\hline
\end{tabular}

All agents were administered p.o. prior to compound histamine. Each experiment consisted of six observations. All inhibitory values indicate mean \pm S.D.

${ }^{a}$ Scratching behavior frequency numbers of normal control, which was treated with saline alone, and control group, which was treated with histamine and saline, for $1 \mathrm{~h}$ were $85 \pm 5$ and $3 \pm 2$, respectively.

${ }^{\mathrm{b}}$ Not determined.

$\mathrm{c}, \mathrm{d}, \mathrm{e}, \mathrm{f}$ Those with the same letter are not significantly different in each column $(P<0.05)$

injection of anti-DNP-HSA. And then RG water extract was orally administered 60 min prior to challenge with DNP-HSA antigen and their inhibitory potency of PCA reaction was measured (Table 1). RG extract potently inhibited PCA reaction, and at doses of 100 and $200 \mathrm{mg} /$ $\mathrm{kg}$ inhibited PCA reaction by 32 and $40.9 \%$, respectively. Therefore, we isolated the representative ingredients, SF and PF, from RG and measured their inhibitory effect against PCA reaction. The saponin fraction potently inhibited the PCA reaction, but the PF did not exhibit the PCA reaction-inhibitory effect.
Table 3. Inhibitory effects of RG and its ingredients on the $\beta$ hexosaminidase release from RBL $2 \mathrm{H} 3$ cells induced by IgE-antigen complex.

\begin{tabular}{cc}
\hline \hline Agent & $\mathrm{IC}_{50}(\mathrm{mg} / \mathrm{ml})$ \\
\hline $\mathrm{RG}$ & $>0.2(32)$ \\
$\mathrm{SF}$ & 0.19 \\
$\mathrm{PF}$ & $>0.2(12)$ \\
Azelastine & 0.02 \\
\hline
\end{tabular}

RBL-2H3 cells, which were grown in DMEM supplemented with $10 \%$ fetal bovine serum and L-glutamine, were dispensed into 24 well plates, at a concentration of $5 \times 10^{5}$ cells per well, and sensitized using $0.5 \mu \mathrm{g} / \mathrm{ml}$ of mouse monoclonal IgE. They were then washed with $500 \mu \mathrm{l}$ of siraganian buffer, exposed to test agents for $20 \mathrm{~min}$, and treated with $20 \mu \mathrm{l}$ of antigen (DNP-HSA, $1 \mu \mathrm{g} / \mathrm{ml}$ ) for $10 \mathrm{~min}$ at $37^{\circ} \mathrm{C}$. The release of $\beta$-hexosaminidase from RBL-2H3 cells was measured according to the method of Choo et al. ${ }^{18)}$ The values in parenthesis indicate degranuationinhibitory percent at a dose of $0.2 \mathrm{mg} / \mathrm{ml}$.

Inhibitory activity of RG and its ingredients on histamine-induced scratching behaviors in mice

To evaluate the antiatopic effect of RG, we measured the inhibitory effects of RG and its ingredients on histamine-induced scratching behaviors in mice. RG and its SF potently inhibited scratching behaviors. However, PF did not inhibit it. RG at a dose of $100 \mathrm{mg} / \mathrm{kg}$ and $\mathrm{SF}$ at a dose of $50 \mathrm{mg} / \mathrm{kg}$ significantly inhibited the scratching frequency by $32 \%$ and $38 \%$, respectively. RG and SF also reduced the vascular permeability of skin induced by compound 48/80 (Data not shown). Their inhibitory activities against vascular permeability were proportion to their inhibitions against scratching behaviors.

Inhibitory activity of RG and its ingredients against degranulation of RBL-2H3 cells

To evaluate the inhibitory mechanism of RG against PCA and scratching behavior reactions, their inhibitory effect in $\beta$-hexosaminidase release (degranulation) of RBL-2H3 cells induced by IgE-complex was investigated (Table 1). RG and SF all inhibited the degranulation of RBL-2H3 cells. Among them, SF potently inhibited it. However, PF did not inhibit it.

Inhibition of RG and its ingredients on cytokine production of RBL-2H3 cells

The inhibitory effects of RG and its ingredients against protein expression of TNF- $\alpha$ and IL-4 were also measured in RBL-2H3 cells stimulated by IgE-antigen complex by the analysis of RT-PCR analysis (Fig. 1). RG and its ingredients inhibited the mRNA expressions of TNF- $\alpha$ 


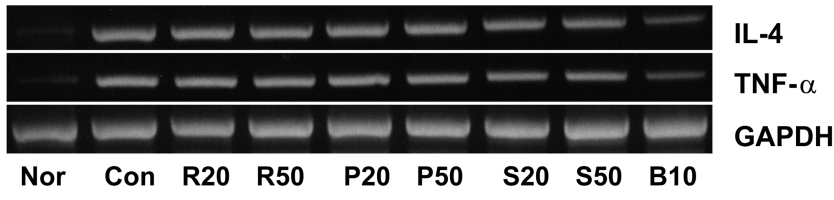

Fig. 1. The effects of $R G$ and its ingredients on the mRNA expression of TNF- $\alpha$ and IL- 4 in RBL-2H3 cells induced by the IgE-antigen complex. RBL-2H3 cells $\left(2.5 \times 10^{6}\right.$ cells $)$ were treated with $0.5 \mu \mathrm{g} / \mathrm{mL}$ of mouse monoclonal IgE for $1 \mathrm{~h}$, and then exposed to $0.2 \mathrm{~mL}$ of the test agents [N, normal; C, vehicle alone; R20, $20 \mu \mathrm{g} /$ $\mathrm{ml}$ of red ginseng (RG); R50, $50 \mu \mathrm{g} / \mathrm{ml}$ of RG; P20, 50 $\mu \mathrm{g} / \mathrm{ml}$ of polysaccharide fraction (PF); P50, $50 \mu \mathrm{g} / \mathrm{ml}$ of $\mathrm{PF}$; S20, $20 \mu \mathrm{M} / \mathrm{ml}$ of saponin fraction (SF); S50, 50 $\mu \mathrm{M} / \mathrm{ml}$ of SF; B10, $10 \mu \mathrm{M}$ betamethasone) for $20 \mathrm{~min}$, followed by treatment with $0.2 \mathrm{~mL}$ dinitrophenol-human serum albumin (DNP-HSA, $1 \mu \mathrm{g} / \mathrm{mL}$ ) for $1 \mathrm{~h}$ at $37^{\circ} \mathrm{C}$, and then RT-PCR for TNF- $\alpha$ and IL- 4 were performed. Normal (Nor) was treated with vehicle alone instead of agents and IgE-antigen complex.

and IL-4. Of them, SF most potently inhibited the mRNA expressions of TNF- $\alpha$ and IL-4.

\section{DISCUSSION}

Allergic diseases such as atopic dermatitis, asthma, allergic rhinitis, and food allergy afflict up to $20 \%$ of the human population in most countries ${ }^{18)}$. The etiology of allergy reactivity is based on IgE-medicated pharmacological processes of a variety of cell populations such as mast cell and basophils ${ }^{19}$. Degradation of mast cells and basophils with antigen-crosslinked IgE releases histamine, prostaglandins, leukotrins and cytokines affecting lymphocytes, macrophages, eosinophils and neutrophils. Finally cytokine-induced reaction causes tissue damages such as atopic dermatitis. Therefore, antiatopic dermatitis with antiPCA reaction and/or antiscratching behavior actions may be beneficial agents for allergic diseases.

RG and its SF potently inhibited PCA reaction induced by IgE-antigen complex and histamine-induced scratching behaviors. SF inhibited the release of $\beta$-hexosaminidase from RBL-2H3 cells. However, the inhibitory effect of SF was weaker than that of the representative constituents, ginsenoside $\mathrm{Rh}_{2}$, of $R G$ previously reported. This result suggests that $\mathrm{RG}$ almost did not contain the active ginsenoside $\mathrm{Rh}_{2}$. Nevertheless, if RG or its SF is orally administered, its ginsenosides may be metabolized to the ginsenoside $\mathrm{Rh}_{2}$ by intestinal microflora and express the anti-PCA reaction like the previous reports. RG did not exhibit the significant antihistamine effect against guinea pig ileum ${ }^{11)}$, although Tachikawa et al. reported that ginsenoside $\mathrm{Rg}_{3}$ weakly inhibited histamine-induced ileum contractions of guinea-pig ${ }^{10)}$. The previous studies reported that ginsenoside $\mathrm{Rh}_{1}$, compound $\mathrm{K}$ and ginsenoside $\mathrm{Rh}_{2}$ showed more potent membrane stabilizing effect than those of disodium cromoglycate ${ }^{6,7,13)}$. These results suggest that the inhibitory action of these ginsenosides on the release of $\beta$-hexosaminidase may be due to protection of the cytolytic response by antigen-IgE and these ginsenosides after all showed the most potent inhibitory activity on PCA reaction.

RG and its SF also potently inhibited the scratching behaviors (itching) induced by histamine. Iitching, which provokes the desire to scratch, can be local or widespread and associated with atopic dermatitis, uriticaria or systemic disorders (cholestasis, uraemia). Many endogenous chemical agents, like amines, proteases, growth factors, neuropeptides, opioids, ecosanoids and cytokines, can act as pruritogens ${ }^{19-21)}$. Scratching can cause skin lesions and contribute to severe psychological disturbances ${ }^{22}$, and therefore, inhibition of this response is consistently beneficial for improving the quality of life.

RG, particularly SF, significantly inhibited mRNA expression of proinflammatory TNF- $\alpha$ and IgE-inducing IL-4 in RBL-2H3 cells induced by IgE-antigen complex. These findings suggest that RG can improve allergic skin disorders atopic dermatitis and contact dermatitis by the regulation of TNF- $\alpha$, and IL- 4 produced by mast cells and basophils and their membrane stabilization. Therefore, we believe that RG can show extensive antiatopic and allergic effects and its SF can be a candidate for the therapeutic agent for allergy.

\section{ACKNOWLEGEMENT}

This work was supported by the grant from the Korean Society of Ginseng (2006).

\section{REFERENCES}

1. Tanaka, N., Tanaka, O. and Shibata, S.: Chemical studies on the oriental plant drugs. XXVIII. Saponins and sapogenins of ginseng; Stereochemistry of sapogenin of ginsenoside $\mathrm{Rb}_{1}, \mathrm{Rb}_{2}$ and Rc. Chem. Pharm. Bull., 20, 1212-1216 (1972).

2. Wu, J. Y., Gardner, B. H., Murphy, C. I., Seals, J. R., Kensil, C. R., Recchia, J., Beltz, G. A., Newman, G. W. and Newman, M. J.: Saponin adjuvant enhancement of antigen-spe- 
cific immune responses to an experimental HIV-1 vaccine. $J$. Immunol., 148, 1519-1525 (1992).

3. Kitagawa, I., Yoshikawa, M., Yoshihara, M., Hayashi, T. and Taniyama, T.: Chemical studies on crude drug precession. I. On the constituents of ginseng radix rubura (I). Yakugaku Zasshi 103, 612-622 (1983).

4. Kown, S. W., Han, S. B., Park, I. H., Kim, J. M., Park, M. K. and Park, J. H.: Liquid chromatographic determination of less polar ginsenosides in processed ginseng. J. Chromatogr. A, 921, 335-339 (2001)

5. Kim, W. Y., Kim, J. M., Han, S. B., Lee, S. K., Kim, N. D., Park, M. K., Kim, C. K. and Park, J. H.: Steaming of ginseng at high temperature enhances biological activity. J. Nat. Prod. 63, 1702-1704 (2000)

6. Park, E. K., Choo, M. K., Han, M. J. and Kim, D. H.: Ginsenoside $\mathrm{Rh}_{1}$ possesses antiallergic and anti-inflammatory activities. Int. Arch. Allergy Immunol. 133, 113-120 (2004)

7. Bae, E. A., Han, M. J., Choo, M. K., Park, S. Y. and Kim, D. H.: Metabolism of 20(S)- and 20(R)-ginsenoside $\mathrm{Rg}_{3}$ by human intestinal bacteria and its relation to in vitro biological activities. Biol. Pharm. Bull., 25, 58-63 (2002).

8. Kim, N. D., Kang, S. Y., Kim, M. J., Park, J. H. and SchiniKerth, V. B.: The ginsenoside $\operatorname{Rg}_{3}$ evokes endothelium-independent relaxation in rat aortic rings: role of $\mathrm{K}^{+}$channels. Eur J Pharmacol., 367, 51-57 (1999)

9. Nakata, H., Kikuchi, Y., Tode, T., Hirata, J., Kita, T., Ishii, K., Kudoh, K., Nagata, I. and Shinomiya, N.: Inhibitory effects of ginsenoside $\mathrm{Rh}_{2}$ on tumor growth in nude mice bearing human ovarian cancer cells. Jpn J. Cancer Res., 89, 733-740 (1998).

10. Tachikawa, E., Kudo, K., Harada, K., Kashimoto, T., Miyate, Y., Kakizaki, A. and Takahashi, E.: Effects of ginseng saponins on responses induced by various receptor stimuli. Eur. J. Pharmacol., 369, 23-32 (1999).

11. Bae, E. A., Han, M. J., Shin, Y. W. and Kim, D. H.: Antiallergic and antipsoriatic effects of Korean Red ginseng. $J$. Ginseng Res., 29, 80-85 (2005).
12. Park, E. K., Choo, M. K., Han, M. J. and Kim, D.-H.: Ginsenoside $\mathrm{Rh}_{1}$ possesses antiallergic and anti-inflammatory activities. Int. Arch. Allergy Immunol., 133, 113-120 (2004).

13. Choo, M. K., Park, E. K., Han, M. J. and Kim, D.-H.: Antiallergic activity of ginseng and its ginsenosides. Planta Med., 69, 518-522 (2003).

14. Park, E. K., Choo, M. K., Oh, J. K., Ryu, J. H. and Kim, D. H.: Ginsenoside $\mathrm{Rh}_{2}$ reduces ischemic brain injury in rats. Biol. Pharm. Bull., 27, 433-436 (2004).

15. Yang, S. H., Seo, S. H., Kim, S. W., Choi, S. K. and Kim, D. H.: Effect of ginseng polysaccharide on the stability of lactic acid bacteria during freeze-drying process and storage. Arch. Pharm. Res., 29, 735-740 (2006).

16. Sugimoto, Y., Umakoshi, K., Nojiri, N. and Kamei, C.: Effect of histamine H1 receptor antagonists on compound 48/80induced scratching behavior in mice. Eur. J. Pharmacol., 351, 1-5 (1998).

17. Shin, Y. W., Bae, E. A., Kim, S. S., Lee, Y. C. and Kim, D. $\mathrm{H}$.: Effect of ginsenoside $\mathrm{Rb}_{1}$ and compound $\mathrm{K}$ in chronic oxazolone-induced mouse dermatitis. Int. Immunopharmacol., 5, 1183-91 (2005).

18. Bachert, C. and van Cauwenberge, P.: The WHO ARIA (allergic rhinitis and its impact on asthma) initiative. Chem. Immunol. Allergy, 82, 119-126 (2003).

19. Stevens, R. L. and Austen, K. F.: Recent advances in the cellular and molecular biology of mast cells. Immunology Today 10, 381-386 (1989)

19. Lerner, E. A.: Chemical mediator of itching. In: Berhard J, editor. Itch: mechanisms and management of pruritis. New York: McGraw-Hill; 1944, p.23-25.

20. Hagermark, O.: Itch mediators. Semin Dermatol., 14, 271276 (1955).

21. Schmeiz, M., Schmidt, R., Bickel, A., Handerker, H. O. and Torebjork, H. E.: Specific C-receptors for itch in human skin. J. Neurosci., 17, 8003-8008 (1997).

22. Raid, D. S.: Pruritis of chronic cholestasis. Q. J. Med., 88, 603-607 (1955). 